\title{
Motivation And Job Satisfaction of Physical Education Teachers During Pandemic
}

\author{
DOI: $10.26466 /$ opus. 887856
}

*

\author{
Aysel Kızılkaya Namlı* - Mehmet Akif Yücekaya** \\ * Assoc. Prof, Munzur University \\ E-Mail: ayselkizilkaya@hotmail.com \\ ORCID: $\quad$ 0000-0001-7980-421X \\ ** PhD student, İnönü University \\ E-Mail : yucekayaakif@gmail.com \\ ORCID: $\quad \underline{0000-0003-3853-5660}$
}

\begin{abstract}
This research aims to determine the motivation and job satisfaction of physical education teachers during the pandemic. For this purpose, phenomenological design, one of the qualitative research methods, was used in the research. The sample of the study consists of 16 physical education teachers who teach in distance education during the pandemic. Descriptive and content analysis was used in the analysis of the research. According to the results of the research, physical education teachers cannot spend effective time while providing distance education during the pandemic. They stated that the reason for this is that it is not like face-to-face education. Almost all of the physical education teachers stated that the lessons they give in distance education are not efficient. It is also stated in the results of the research that teachers and students have a low desire to participate in the course and the conditions are not suitable during the pandemic. In this process, it was determined that teachers thought this was a temporary process and motivated both themselves and their students. As a result of the research, most of the teachers stated that they could not get job satisfaction. At the same time, it was revealed that the majority of teachers were unable to open exercises, dyk courses and elective sports courses were not preferred by the school administrations, resulting in low additional course fees and this situation caused financial problems.
\end{abstract}

Keywords: Pandemic, Physical education teachers, Distance education, Motivation, Job satisfaction. 


\section{Pandemi Sürecinde Beden Eğitimi Öğretmenlerinin Motivasyonu ve İş Doyumu}

\section{Öz}

Bu araştırmanın amacı pandemi sürecinde beden eğitimi öğretmenlerinin motivasyonu ve iş doyumunu belirleyebilmektir. Bu amaçla araştırmada nitel araştırma yöntemlerinden olgubilim deseni kullanılmıştır. Araştırmanın örneklemini pandemi sürecinde uzaktan eğitimde ders veren 16 beden eğitimi öğretmeni oluşturmaktadır. Araştırmanın analizinde betimsel ve içerik analizi kullanılmıştır. Araştırma sonuçlarına göre pandemi sürecinde uzaktan eğitim verirken beden eğitimi öğretmenleri etkili zaman geçirememektedir. Bunun sebebi olarak ise yüz yüze eğitim gibi olmadığın ifade etmişlerdir. Beden eğitimi öğretmenlerinin tamamına yakın uzaktan eğitimde yaptıkları derslerin verimli olmadı̆̆ın belirtmiştir. Pandemi sürecinde öğretmen ve öğrencilerin derse katılım isteğinin düşük olduğu ve şartlarm uygun olmaması da araştırma sonuçlarında yer almaktadır. Bu süreçte öğretmenler bunun geçici bir süreç olduğunu düşünerek hem kendilerini hem de öğrencilerini motive ettiği belirlenmiştir. Araştırma sonucunda öğretmenlerin büyük bir çoğunluğunun iş doyumu sağlayamadığı belirlenmiştir. Bu sonuca paralel olarak yine büyük bir çoğunluğunun bu süreçte ek ders kesintisi olmasının kendilerine ve ailelerine sorun yarattı̆̆ııı sonucuna ulaşılmıştır.

Anahtar Kelimeler: Pandemi süreci, Beden eğitimi öğretmenleri, Uzaktan eğitim, Motivasyon, İş dоуити 


\section{Introduction}

In January 2020, an Internationally Important Public Health Emergency was declared by World Health Organization (WHO) due to the outbreak of a new disease, COVID-19 (WHO, 2020). It was declared a pandemic by the World Health Organization in March 2020 due to the spreading rate and the increase in the countries where it is seen (Şenol and Bilsel, 2020). Due to the rapid spread of the pandemic across countries, many countries have made radical decisions. Within the scope of the decisions taken, a short break was given to education and training at all levels, and then it was decided by the Higher Education Institution and the ministries that education would continue in digital environments in education and training remotely. The existence of past research on distance education in Turkey (Bozkurt, 2017) has enabled easy adaptation to this process caused by the pandemic (Serçmeli and Kurnaz, 2020).

During this period, different difficulties and restrictions may be encountered within the context of distance education. For example, the lecturer's limitations in the pandemic process, the lack of internet and technological devices in the region where they are located, their knowledge in computer use, their feelings and thoughts about distance education, whether they have a computer or not, their feelings and thoughts about the pandemic (Bakioğlu and Çevik, 2020), all of which confuse people's minds.

Education has been suspended all over the world and in our country and the transition to distance education has been in a very rapid process (Bozkurt, 2020; Gewin, 2020; Lau, Yang and Dasgupta, 2020; Keskin and Özer Kaya, 2020; Telli-Yamamoto \& Altun, 2020). It is thought that many reasons during the pandemic such as home training, strict measures taken in daily life, excessive time spent for educational purposes in front of computers or technological devices will seriously affect teachers and students. Based on learner and teacher, it can be said that distance education will cause motivational problems for both sides. Motivation is a driving force that energizes the individual, creates a substructure in explaining his behaviour, and makes him more willing. It determines the direction, level, determination of an individual's behaviour, and speed in achieving the desired goal in the educational environment (Martin, 2001; Elliot and Covington, 2001; Meece, et al., 2006). Motiva- 
tion is defined as a complementary and progressive force that mobilizes individuals, guides their behaviour, and makes this movement continuous. In other words, motivation is the power that enables individuals to reach their goals with their instincts and self-determination to reach their goals (Çelik, 1999; Özdemir and Cemaloğlu, 2017; Robbins, Coulter and DeCenzo, 2017). Huitt (2011) motivation, the internal state or situation that activates and directs the behaviour; desire or desire that stimulates and directs targeted behaviour; defines it as the effect of needs and desires on the intensity and direction of behaviour. Encouragement to act refers to a self-determining choice and relates to expressions of one's sense of personal power and autonomy (Deci and Ryan, 1985). Locke (1997) stated that motivation is determined by goal orientation, human will or free will, and perceived needs and desires, which continue the actions of individuals regarding themselves and their environment. Motivated employees are needed to keep up with rapid changes in workplaces. Motivated employees help organizations survive. Motivated employees become more productive, and to be effective, managers need to understand what motivates them in the context of their roles. Of all the functions a manager performs, motivating employees is arguably the most complex. This is because what motivates employees is constantly changing (Bowen and Radhakrishna, 1991). Based on these expressions, it can be said that motivation is an important tool in ensuring the continuity of the organization and the functioning within the organization. In educational organizations, it is important to keep the functioning smooth.

The distance education being carried out during the pandemic period first worried the teachers and the education community. Some problems have occurred in the process of keeping up with this situation experienced for the first time. At the spring of these problems is the fact that such a situation has not been experienced before (Sar1 and Nayrr, 2020). Distance education, which can bring teachers and learners from different places together, while teaching such subjects and causing a decrease in motivation in the learner, provides great benefits in terms of controlling the time effectively between situations that increase motivation. In this way, learners have the opportunity to enter any lesson wherever and whenever they want (Akbal and Akbal, 2020). In this process, it is thought that there will be differences in terms of job satisfaction due to the narrowing of the working areas of teachers. 
Job satisfaction is related to the concepts of pleasure from the job, motivation, morale, commitment to work, and desire to go to work. Whereas motivation requires working for a purpose; job satisfaction refers to pleasure gotten from the job. In this context, job satisfaction is the happiness and pleasure that an individual obtains by reviewing his / her job and business life (Başaran, 1991). Job satisfaction is the positive psychology and endogeneity that occurs as a result of an individual's work experiences (Çelik, 1999). The emotional response of an individual about his job is job satisfaction. It is therefore not tangible, not visible, it can only be described (Baş, 2002). Satisfaction or dissatisfaction with the workplace is important. In other words, satisfaction is an expression of job satisfaction, while dissatisfaction is an expression of not achieving job satisfaction (Günbayı, 2000). The emotional state, behavior, attitudes, and preferences of individuals towards their jobs (Chen, 2008) constitute the infrastructure related to job satisfaction. If individuals are happy to work in the workplace, enjoy their work, have a good and peaceful environment with their colleagues, and most importantly, if they are not unwilling to go to work, it would be correct to say that job satisfaction is achieved. In the opposite case, the employee cannot provide job satisfaction. It is thought that teachers' motivation will decrease and they will not be able to achieve job satisfaction in an education system that is not face-to-face.

All these situations have led physical education teachers who have never had distance education experience before, into great difficulty, into obscurity and chaos. The lessons taught by doing and acting in front of the students are now captive to the camera and microphone. In this case, it puts students and teachers in a big deadlock. For this reason, it is assumed that teachers of physical education classes, which is a practical course, have difficulties in adapting to the process during the pandemic. In this study, the aim was to determine the motivation and job satisfaction of physical education teachers during the pandemic. For this purpose, the answers to the following questions were sought.

1. Can you spend effective time with students during the pandemic?

2. Has the lesson you taught in this period been effective for you?

3. How is your and your students' desire to participate in the lesson during the pandemic?

4. Can you achieve job satisfaction during the distance education process?

5. How do you motivate yourself and your students during the pandemic? 
6. What do you think about decreasing the number of your lessons during the pandemic (no dyk courses, exercise, and elective sports classes)?

Among the research questions, effective time spent (question 1), the efficiency of the lesson (question 2), job satisfaction in the distance education process (question 4), and reduction in the number of lessons (question 6) are questions to determine job satisfaction; the questions of your and your students' desire to participate in the lesson (question 3), how do you motivate yourself and your students (question 6) were evaluated as questions to determine motivation.

\section{Methodology}

\section{Research Model}

The qualitative research method was used in the research. Qualitative research has been defined as a long-term, large-scale study that has different aspects within its own framework in which the cases are accommodated (Saban, 2007). Phenomenological design, one of the qualitative research models, was used in the study. Phenomenological studies, to make sense of the information that people experience about a concept, phenomenon, or events (Ertürk Kara and Gözcü, 2015); involves the participants putting forward their opinions comprehensively about the facts or situations by investigating and analyzing the individual experiences of the facts or situations in depth (Yıldırım and Şimşek, 2013). In the phenomenological study method, data is collected mostly through interviews (Ylldırım and Şimşek, 2013).

\section{Study Group}

The simple random sampling method, which is one of the sampling methods, was used in determining the study group. Simple random sampling is the most basic sampling method; it is a sampling method in which every member of a population has the same chance of being included in the sample and all possible samples of a certain size have the same chance of selection (West, 2016). The study group of the research consists of 16 physical education teachers who are currently working in Elazig and have online lessons. The demographic characteristics of physical education teachers participating in the study are given in Table 1 below. 
Table 1. Characteristics of the study group

\begin{tabular}{llll}
\hline Variables & & f & \% \\
\hline \multirow{2}{*}{ Gender } & Female & 4 & 25 \\
& Male & 12 & 75 \\
\hline \multirow{2}{*}{ Period of service } & 1-5 Years & 12 & 75 \\
& 6-10 Years & 4 & 25 \\
\hline \multirow{2}{*}{ Type of school } & Middle school & 12 & 75 \\
& High school & 4 & 25 \\
\hline \multirow{2}{*}{ The number of courses } & 1-15 Hours & 10 & 62,5 \\
& 15-30 Hours & 6 & 37,5 \\
\hline
\end{tabular}

The majority of the participants in the study are male teachers, those with a seniority of 1-5 years, those working in secondary schools and teachers with 1-15 hours of live class hours.

\section{Data Collection Tool and Data Collection}

In the study, a semi-structured interview form was used to determine the motivation and job satisfaction levels of physical education and sports teachers in the study group during the pandemic. Halcomb and Andrew (2005) stated that interviews would be suitable for qualitative research because of the emphasis on researching and questioning human phenomena. In-depth interviewing has the distinctive features of being an open situation and allows new research directions to emerge using techniques such as research (Berry, 1999). The data collection tool prepared was examined by two academicians who are experts in the field, and after the final form of the interview form was given, it was applied to the participants. The semi-structured interview form consists of two parts. In the first part, there are 4 questions to determine the demographic characteristics of the group, and in the second part, there are 6 questions including research questions. In the study, since it was thought that it would be inconvenient to meet face-to-face due to the pandemic, the data were collected by making phone calls with the participants. First of all, the participants were informed about the research, and an appointment was made for an appropriate time period. When the appointment time came, the participants were called, and a sound recording was taken to analyse the data properly after their approval was obtained. The interview time with each participant lasted approximately 15-25 minutes. The recorded sound recordings were transferred to digital media and analysis was started after the participant's confirmation was obtained. 


\section{Data Analysis}

The data obtained from the research were subjected to descriptive and content analysis, which is frequently used in qualitative research methods. Descriptive analysis was used in the process of determining the titles according to the research questions and creating themes, and content analysis was used in analysing the participant answers.

\section{Validity and Reliability}

Reliability and validity are defined as ways of demonstrating and communicating the rigor of research processes and the reliability of research findings (Roberts and Priest, 2006). To have a study accepted by the scientific community, it is important to have a validity assurance (Morse, Barret, Mayan, Olson and Spiers, 2002). Some criteria must be fulfilled to ensure the validity and reliability of the study. In qualitative research, the concept of "validity" is used to prove the accuracy of scientific findings, and "reliability" is used to prove the reproducibility of scientific findings (Yıldırım and Şimşek, 2013). As the criteria for the validity of the study, it should be tried to ensure that the studies measure or test what is actually intended and the applicability of the findings in a similar environment should be ensured (Lincoln \& Guba, 1985). In order to ensure validity in the research, firstly, all the details of how conceptual categories were reached were given. While analysing the opinions of the participants, groupings were made according to the similarity of the expressions used and each participant was given a code (such as P1, P2, P3 ...).

The reliability of the study is related to the consistency and repeatability of the findings (Lincoln and Guba, 1985; Merriam, 2009). It means that the research gives the same result in similar conditions, similar environments. In order to ensure the reliability of the study, a non-research expert opinion was received. In order to determine whether the answers obtained from the participants' opinions represent the theme on which they were placed, the expert outside the field was asked to be placed in themes in a way that no answer was left out. At the end of this stage, the matches made by the researchers and the experts outside the field were compared. At the end of the comparison, the number of consensus and disagreement of researchers and experts from 
outside the field was determined. The reliability formula of Miles and Huberman was used to ensure the reliability of the study. The study is considered to be reliable when the agreement between the researcher and the expert is $70 \%$ and above (Ylldırım \& Şimsek, 2013). Since the reliability rate was found to be $88 \%$ in the study, it can be said that the study is reliable. In addition, the raw data and coding collected for research are kept for later review by those concerned.

\section{Results}

This section is presented in six titles based on research questions. In this part of the research, the findings of the results of the research questions are included.

\section{Reasons for the Inability to Spend Effective Time with Students During Pandemic}

In the study, the participants were asked "Can you spend effective time with the students during the pandemic process?". Since none of the participants stated that they had an effective time, answers were obtained for the reasons for not having an effective time. Participant views are given in Table 2 below.

Table 2. Reasons for the inability to spend effective time with students during pandemic

\begin{tabular}{ll}
\hline Theme & Code \\
\hline \multirow{3}{*}{$\begin{array}{l}\text { Reasons for the inability to spend } \\
\text { effective time with students during the } \\
\text { pandemic }\end{array}$} & Not being efficient like face-to-face education is \\
\cline { 2 - 2 } & Network problems \\
\cline { 2 - 2 } & Not being able to reach the student \\
\cline { 2 - 2 } & \begin{tabular}{l} 
Students' not having access to a PC or a smartphone \\
\cline { 2 - 2 }
\end{tabular} \\
\hline
\end{tabular}

First of all, all of the teachers who participated in the study stated that they did not have an effective time. They stated that the reasons for not being able to spend effective time with their students are due to the fact that distance education is not as effective as face-to-face education and that there is an internet problem. Some quotations from the opinions of the participants are given below. 
- "......Even if we can see each other on a screen, we cannot get that efficiency as long as they are not face-to-face. Not only talking, but a smile to the child, a gesture and even a facial expression provide a magnificent sincerity and a beautiful communication between us. But from a distance, that's not possible I think that's the reason." $P 7$

- "I cannot spend effective time. We cannot reach most students. Since we communicate over the internet, we cannot reach students because most students do not have internet or mobile communication channels. And for the ones we can reach, we cannot establish an effective communication because they have internet problems..." 11

- ".... Because, we have difficulties in distance education with children just like in face-to-face education. And our physical education branch is not a very efficient one without contact, I cannot show children how to hold a ball in distance education..." P4

- "I cannot spend effective time with students during the pandemic because I like looking in the eyes of my students, I like being in the same environment with them and breathing the same atmosphere. I like to play games with them in the school garden or on the football field. How can I spend effective time in front of the microphone in front of the camera while three or four students attend our lessons, and we give them basic information that we call theoretical, I do not think they are very effective because the child takes no notice of them? Of course, without being face-to-face, side by side, it is not an effective process, an effective time." P14

\section{Efficiency of the Lessons Taught During the Pandemic}

In the research, the participants have been asked "Is the lesson you teach during the pandemic process efficient for you?". Participant opinions are given in Table 3 below.

Table 3. Efficiency of the lessons taught during the pandemic

\begin{tabular}{ll}
\hline Theme & Code \\
\hline & Lack of opportunity to Show and have it done \\
\cline { 2 - 2 } $\begin{array}{l}\text { Efficiency of the Lessons Taught } \\
\text { During the Pandemic }\end{array}$ & \begin{tabular}{l} 
Hot as efficient as face to face \\
\cline { 2 - 2 }
\end{tabular} \\
\cline { 2 - 2 } & Lack of attendance as in other classes \\
\hline & Inability to teach the course in front of the camera \\
\hline
\end{tabular}


Almost all of the participants stated that the lesson was not efficient. They stated the reasons for the ineffectiveness of the lesson, such as the lack of opportunity to show and have it done and the fact that it is a lesson requiring contact. Exact quotations of the participants are given below.

- "It is really difficult to make this efficient in distance education because it is literally efficient since we use more of the demonstration technique that requires one-to-one contact; with the efforts of the students, our own efforts, the efforts of the school administration, we try to make this efficient, but of course, it is more difficult to teach the lesson more efficiently with distance education in this process, especially in the lessons such as visual arts and music based on social activities just like physical education "P11

- "It certainly is not, it is a branch that needs to be done by making a demonstration based on the contact or by touching the student, so no matter how much we want in the online lesson or in front of the camera, we cannot contribute much unless we are not with the child." $P 3$

- "...The motivation of the student is low, and the motivation of the teacher is also low because there is a perception towards physical education lesson, there is a different perception than other lessons, so there is a big difference between attendance rates in other lessons and physical education attendance rate. Unfortunately, the motivation of the teacher may decrease due to the attendance rate of students in physical education classes." P13

- " "....... I do not think it will be an efficient lesson in distance education; I do not think physical education, music, or painting will be efficient. I never think that the lesson will be productive after I cannot hold my student's hand and say that this movement is done like this and you have to correct it." P14

\section{The desire of teachers and students to participate in the lesson during the pandemic}

In the research, the participants have been asked, "How is your and your students' desire to participate in the lesson during the pandemic?". Participant opinions are given in Table 4 below. 
Table 4. The desire of teachers and students to participate in the lesson during the pandemic

\begin{tabular}{ll}
\hline Theme & Code \\
\hline & Low desire in both sides \\
\cline { 2 - 2 } The desire of teachers and students to partic- & Unsuitability of the conditions \\
\cline { 2 - 2 } ipate in the lesson during the pandemic & Resire in both sides \\
\cline { 2 - 2 } & Reluctance due to inactivity \\
\cline { 2 - 2 } & Lot being included in the main courses \\
\hline
\end{tabular}

The majority of the participants in the study stated that their willingness to participate in the lesson was low both for themselves and for their students. They cited various reasons such as the unsuitability of the conditions (lack of phone-tablet-internet), the physical education lesson not being included in the main courses, that is, it is not a course for the exam. Some participants, on the other hand, stated that there is a high desire for participation in the lesson among both sides. Quotations related to the opinions of the participants are given below.

- "Their willingness to participate is very low in other classes as well, but especially in physical education classes are very low in ten percent - eight percent, for example, sometimes 5 people, sometimes 6 , sometimes 3 people in a class of 40 people. Unfortunately, students' desire to participate online in physical education classes is extremely low during this period. My motivation for participating in the online physical education class is not in the desired direction because I cannot do the physical education course online, I cannot do the level I want ........" P13

- "Of course, our students want to attend the lessons, even if they stay away from the school, the students contribute to the lessons by participating from their homes, but unfortunately, due to the lack of internet and the lack of some infrastructure, some students cannot download the zoom, eba programs, and our students have serious difficulties as a result of these difficulties most of them cannot participate in the distance education process. As a result, we are educators both face to face both in distance education, of course, we have to do our best to follow the students, teach our students, guide our students, so let me tell it for me, I do not have the slightest problem on my side. I believe that I did my best in this process ...." P10

- " "'.... I can say that the kids' enthusiasm is very low, the child is listening to lessons via eba, but internet connection cuts off, screen freezes, there are some without television and internet, there are people who cannot use the phone, there 
are students who cannot provide maintenance because they have old phones. It is a complicated situation." P7

- "This system is a new system in our country, it is not fully developed including exam-oriented branches, our students cannot give a hundred percent of mathematics lessons, so when we have live lessons as we want in physical education class, we start classes and wait for the students for half an hour. However, the participation of our students constitutes a very small 10 percent. " P3

\section{Teachers' Ways to Motivate Themselves and Their Students during the Pandemic}

"How do you motivate yourself and your students during the pandemic process?" was asked to the teachers and their views were received. The opinions of the teachers are given in Table 5 below.

Table 5. Teachers' ways to motivate themselves and their students during the pandemic

\begin{tabular}{|c|c|}
\hline Theme & Code \\
\hline \multirow{8}{*}{$\begin{array}{l}\text { Teachers' Ways to Motivate } \\
\text { Themselves and Their Students } \\
\text { during the Pandemic }\end{array}$} & Being a temporary process (a common way to motivate) \\
\hline & Not being motivated (for teachers) \\
\hline & Loving the profession (for teachers) \\
\hline & Orienting towards personal development (for teachers) \\
\hline & Meeting with colleagues (for teachers) \\
\hline & To do different activities (for students) \\
\hline & Talking about the old days (for students) \\
\hline & Forming private groups with students (for students) \\
\hline
\end{tabular}

Most of the teachers participating in the study stated that they motivated and have been motivated by reminding both themselves and their students that these days are temporary, that it is an extraordinary situation, and that they will come together again. In addition, there are also teachers who try to motivate their students but state that they are not motivated themselves. Another method used to motivate students was stated as activities such as playing games and watching videos. Some of the opinions of the participants are given below.

- "These times will pass, we will switch to formal education again, we will run and play in our garden again, you will play with the balls again. Students who are successful in some branches will still be engaged in that branch, I try to make them happy in this way, I try to motivate us that these times will pass, and we will meet in our school garden again. " P4 
- "I think the same thing that I say to my children, I think this process will end one day or even soon, and I console myself by saying this. We will not wear a mask until the end of our life, we will not live these extraordinary measures with such anxiety. Of course, there will be an end, but maybe today, maybe a year later ..." P7

- "...... when we consider the memories, we have lived in the past, we are given a lesson to live more beautiful ones, we should consider it as a lesson, we should consider these processes as a process that we need to see and turn to ourselves in order to appreciate them. That is why I am trying to express to them that there are processes that have been passed, but after these, good days come next. " P2

- " ".... During this period, I stayed at home for 14 days and in the meantime, I read books and read a book about Atatürk, I also finished a book called "The Teacher Must See the Tree at the Seed" during this 14-day period, there were a few films that I watched. In other words, by doing these, one should look for ways to motivate oneself by following a little bit of daily life. " P10

- "... I cannot motivate myself in this process, frankly, we play polyannaism for children, but we cannot motivate ourselves because we are always at home because I was a person who worked 6 days a week before that. Only Thursday was empty last year, I was full even on Saturday and Sunday, I had a volleyball team, I was coaching it. I was so active that I fell into such a passive situation obviously lowers my motivation and I cannot improve my motivation because my motivation is always low. This is such a process. P14

\section{Teachers' Job Satisfaction in Distance Education}

"Are you able to have job satisfaction in the process of distance education?" was asked to the teachers participating in the study and their opinions were taken. These opinions of teachers are given in Table 6 below.

Table 6. Teachers' job satisfaction in distance education

\begin{tabular}{ll}
\hline Theme & Code \\
\hline & Failure to teach courses in their own field \\
\cline { 2 - 2 } Teachers' Job Satisfaction in Distance & Not being face to face with the student \\
\cline { 2 - 2 } Education & Restriction of mobility \\
\cline { 2 - 2 } & Inability to teach \\
\cline { 2 - 2 } & Requiring psychomotor skills \\
\cline { 2 - 2 } & Inability to exercise at home \\
\hline
\end{tabular}


A great majority of the participants stated that they could not achieve job satisfaction. Only one of the teachers stated that he achieved job satisfaction and one of them stated that he partially achieved job satisfaction. Some of the participants stated that because they are not in the field, that is, they are not with the students, and that their mobility is restricted has a negative effect on their job satisfaction. Some quotations from the opinions of the participants are given below.

- "..... because it is different now even, I want to hit the ball or run to the children, I want to get that fresh air, it is very difficult for us, for all teachers ...." P11

- "... because I do not enjoy my work, okay, we have children do activities in distance education. We ask questions. We tell them that they have to do these things, but without being with them, without being able to play a football match, a handball match with them, or without being able to take them to the tournaments on the Astroturf, seeing them yelling, laughing, having fun, even falling and injuring, I do not get satisfied with my job and in order for me to be satisfied, I have to be with them again and even create five or six school teams in one semester and I have to take these children to tournaments constantly. " P14

- " "... since I do not make eye contact with the student, and there is no classroom environment, unfortunately, little or no learning occurs, so there is no job satisfaction ..." P13

- "...... We are people who like to be in school and run with the children. We cannot enjoy this profession unless we do these movements ourselves and we run with the children and do that branch. "P2

\section{Teachers' Opinions on Reducing the Number of Lessons During the Pandemic}

To the teachers who participated in the research, "What do you think about reducing the number of your lessons during the pandemic (support and training courses, exercise and elective sports lessons)?" was asked to the teachers participating in the study and their opinions were received. The opinions of the participants are given in Table 7.

Table 7. Teachers' thoughts on reducing the number of lessons (lack of dyk courses, exercise, and elective sports classes) during the pandemic

\begin{tabular}{ll}
\hline Theme & Code \\
\hline \multirow{2}{*}{$\begin{array}{l}\text { Teachers' Opinions on Reducing the Number of Les- } \\
\text { sons During the Pandemic }\end{array}$} & Affected financially \\
\cline { 2 - 2 } & Perceived as unfair \\
\cline { 2 - 2 } & Perceived as normal \\
\hline
\end{tabular}


The majority of the participants in the study stated that they had difficulty financially, because of the closure of the courses, the interruption of the exercises, or the interruption of additional lessons due to the fact that the elective sports lessons were not preferred by the school administrations, and that they were forced to get on with the additional lessons. Two of the participants stated that it was unfair to open these courses and take additional courses in this process. There is only one participant who regards this situation as normal. Some of the participant views are given below.

- "I did not receive any additional tuition fees during this period. Dyk courses are closed, there is no exercise anyway. Unfortunately, I made some of my plans on additional lessons. These plans failed because I did not take additional lessons, and unfortunately, I am telling them about my problems when I need to devote my time to students. In a way, it is not a good situation for both me and my students, as I do not charge for additional tuition, so I convey certain problems. That is to say, this is reflected negatively on us, therefore we are suffering, and we still continue to suffer because I do not have additional lessons and I cannot take additional lessons because I have 10 hours in physical education class, and this disrupts our plans. " P10

- "In fact, our lesson hours are already few and most of my friends cannot even fill in wages. But while education was continuing, elective courses were given, we had courses and exercises, which relaxed us. The absence of these additional lessons, in other words, the interruption of lessons caused me as a teacher, of course, dejection and discomfort ..." P13

- "During this period, there was a decrease in our lesson hours since additional sports lessons were not opened. We were also increasing our number of additional lessons with dyk courses and exercises, unfortunately, we cannot open them in this process, so we are experiencing financial difficulties... "P11

- "I think it is normal since there is no one-to-one training, it is normal that the courses and exercises cannot be done in distance education. There is not even a lesson, therefore there are no additional lessons ..." P6

\section{Discussion and Conclusion}

With the emergence of the Covid-19 pandemic, numerous changes have occurred in the field of education (Sá \& Serpa 2020). During the pandemic pro- 
cess, in parallel with health-related measures, governments have made a decision for distance education within the framework of available facilities in order to ensure continuity in education and to prevent students from falling into a gap in this process (Telli-Yamamoto and Altun, 2020). In this process, it is seen that countries mostly use distance education opportunities supported by different technological infrastructures in order to ensure that education continues without interruption (Can, 2020). The European Physical Education Association (2020) sent a questionnaire to 41 European Physical Education Union members in 37 European countries to reveal the current status of physical education lessons in European countries during the pandemic process, and 39 members responded to this questionnaire. According to the responses of the members, in $41 \%$ of the member countries, schools are closed, and physical education classes are part of the home education system; $38.5 \%$ of them stated that schools are open and physical education lessons are limited and continue within the scope of recommendations; $15.4 \%$ of them stated that schools are open but physical education classes are cancelled. In our country, which is one of the countries participating in the survey, a decision was made to conduct physical education classes through distance education.

In this study, it is aimed to determine the motivation and job satisfaction of physical education teachers who continue their lessons with distance education during the pandemic process. The interviews were carried out under the headings of teachers' spending effective time with students during the pandemic process, the efficiency of the lesson being taught, the desire of teachers and students to participate in the lesson, the ways teachers motivate themselves and their students, teachers' job satisfaction in distance education, and teachers' opinions about the interruption of additional lessons.

In the research, all of the teachers have stated that they did not spend effective time. They have stated that the reasons for not being able to spend effective time with their students are due to the fact that distance education is not as effective as face-to-face education and that there is an internet problem. Lau, Yang and Dasgupta (2020) emphasized that distance education has advantages, but face-to-face education cannot be replaced, and the practical teacher has limitations in providing online education. Demir and Özdaş (2020) found in their study that teachers encountered problems with participation, planning, uncertainty, communication, infrastructure, and education 
information network (EBA) in distance education activities. Özgül, Ceran and Ylldiz (2020) stated in their study that there are problems related to lack of communication, inability to access the internet, and reluctance in distance education. The studies conducted show similarities with the findings of our study.

In the study, the majority of the teachers stated that physical education lessons were not efficient. They stated the reasons for the ineffectiveness of the lesson, such as the lack of opportunity to have it done and the lesson that includes contact. Başar, Arslan, Günsel and Akpınar (2019) stated that teachers' perceptions and opinions about distance education are among the most important factors affecting the efficiency of distance education. Teachers' inability to use different teaching strategies and methods comfortably during distance education (Kurnaz, Kaynar, Barışık and Doğrukök, 2020), physical education is traditionally taught in schools as a practical and applied lesson where students are in close contact with each other and physical contact is common (Varea, González -Calvo and García-Monge, 2020) can be considered to be effective in the lesson being not efficient.

The majority of the participants in the study stated that their willingness to participate in the lesson was low both for themselves and for their students. Various reasons were stated such as the unsuitability of the conditions (not having a phone-tablet-internet), the physical education lesson not included in the main courses, that is, it was not a course for the exam. Some of the participants stated that there was a high desire for participation in the lesson among both sides. In online education, it has been determined that teachers are inexperienced, a complex environment at home, and infrastructure problems (Zhang, Wang, Yang and Wang, 2020). Demir and Özdaş (2020) stated that teachers' educational activities in the Covid-19 process were evaluated in three different ways: satisfactory, inconvenient, and limited. Çakın and Külekçi Akyavuz (2020) stated that teachers experienced problems with parents, problems with students' learning, and communication problems during this process. When considered in terms of physical education, the pandemic threatens individuals of all age groups as well as school-age individuals. This threat increases more with restrictions (going out to the streets, going to shopping malls, going to school, going to sports centres, etc.) and causes physical education lessons and activities to be carried out for children to be important 
(Tison et. al., 2020). However, in the research, it was determined that the participation of the students was low due to the fact that the course was not included in the main courses, that is, it was not perceived as a course for the exam, and that the students' need for movement was not met at a sufficient level, and the internet-related problems were experienced. It can be thought that this situation negatively affects teachers' job satisfaction and motivation

Most of the teachers participating in the study stated that they were motivated by reminding both themselves and their students that these days are temporary, that it is an extraordinary situation, and that they will come together again. In addition, there are also teachers who try to motivate their students but say that they are not motivated themselves. It was also stated that activities such as playing games and watching videos are another method used to motivate students. Çakın and Külekçi Akyavuz (2020) stated that in this process, teachers used methods to motivate students, such as encouraging them for the future, doing health studies, doing supportive activities, to say good words, and making the school feel continuing. This process forces parents and students to solve problems, cooperate, be creative and active (Anderson, 2020). Deniz and Erdener (2016) stated in their study that the motivation of teachers who could not find their hopes and reach satisfaction in their profession also decreased. Based on this result, it can be said that the job satisfaction and motivation of physical education teachers who could not teach their lessons as they wanted during the pandemic process were negatively affected.

A great majority of the participants stated that they could not achieve job satisfaction. Only one of the teachers stated that he provided job satisfaction and one of them stated that he partially provided job satisfaction. Some of the participants stated that a negative situation is created in their job satisfaction because they are not in the field, that is, they are not in their own field, they are not with the students and their mobility is limited. The pandemic has changed the ways teachers teach students and how they communicate with families (Varea, González-Calvo and García-Monge, 2020). In a study conducted with science teachers, teachers were anxious due to the lack of information that may occur in students during this process, they felt inadequate in the distance education process (Bakioğlu and Çevik, 2020), the most challenging factors for teachers were the lack of knowledge about preparing distance education content, technical difficulties, and the intertwining of private 
life and business life (Karadeniz and Zabc1, 2020). In addition, it is stated that because online learning is a versatile process, students require self-efficacy in various fields (Yıldız and Seferoğlu, 2020). It is stated that the pandemic process affects the nature of physical education, distracts it from sociability, limits physical contact, restricts teachers' teaching ways, and this situation changes the role of teachers (Varea \& González-Calvo, 2020). Failure to obtain the desired efficiency from the physical education course, which teachers try to conduct away from their students and students away from their teachers and friends, may have negatively affected teachers' job satisfaction. Van De Berghe et al. (2013) concluded in their study that the motivation of physical education teachers is associated with their emotional burnout levels, and that teachers with high motivation have a low level of emotional burnout. Arr and Canlı (2020) found in their study that the life satisfaction of physical education teachers also affects their job satisfaction. Social isolation applied during the pandemic process may have negatively affected the life satisfaction of physical education teachers and thus their job satisfaction. This process may have negatively affected the motivation of physical education teachers.

The majority of the participants in the study stated that the lack of additional course fees due to the lack of courses and exercises caused financial difficulties for themselves and their families, and they had difficulties because they got along with additional lessons. Two of the participants stated that it is unfair to do the courses and exercises and to take additional lessons in this process. There is only one participant who regards this situation as normal. Can and Soyer (2008) found in their study that there is a positive and significant relationship between the socioeconomic expectations of physical education teachers and job satisfaction. Gençay (2008) concluded in his study that the increase in the monthly income of physical education teachers also positively affects their job satisfaction. Reducing the number of lessons and therefore taking less additional lessons in this process caused economic difficulties for teachers.

As a result, it has been concluded that physical education teachers cannot teach effectively and efficiently to their students during the pandemic process, distance education is not a very suitable method for physical education lesson, teachers and students are reluctant to participate in the lesson, participation in the lesson is low, and their job satisfaction and motivation are low, and they have financial difficulties. 


\section{Kaynakça / References}

Akbal, H., and Akbal, H. İ. (2020). Investigation of the problems related to distance education in the covid-19 pandemic process by the ahp method according to the student's view. Bartm University Journal of Faculty of Economics and Administrative Sciences, 11(22), 533-546. doi.org/10.47129/bartiniibf.795863

Anderson, J. (2020). Brave New World The coronavirus pandemic is reshaping education. Retrieved from https://qz.com/1826369/how-coronavirus-is-changing-education on 10 August 2020.

Arl, Y., and Canl, U. (2020). The interaction between life satisfaction and job satisfaction: a study for physical education teachers. Sports Education Journal, 4(3), 178-186.

Bakioğlu, B., and Çevik, M. (2020). Science teachers' views on distance education in the covid-19 pandemic process. Electronic Turkish Studies, 15(4), 109-129. https://dx.doi.org/10.7827/TurkishStudies.43502

Bass, T. (2002). Determining the job satisfaction profiles of faculty members. Dokuz Eylül University I.I.I.B.F. Journal 17(2), 19-37.

Başar, M., Arslan, S., Günsel, E., and Akpınar, M. (2019). Distance education perceptions of prospective teachers. Journal Of Multidisciplinary Studies In Education, $3(2), 14-22$.

Başaran, İ. E. (1991). Organizational Behavior. 2nd Edition, Gül Publishing.

Berry, R. S. (1999). Collecting data by in-depth interviewing. University of Exeter \& Hong Kong Institute of Education.

Bowen, B. E., and Radhakrishna, R. B. (1991). Job satisfaction of agricultural education faculty: A constant phenomena. Journal of Agricultural Education, 32 (2). 16-22.

Bozkurt, A. (2017). The past, present and future of the distanceeducation in turkey. Journal of Open Education Applications and Research, 3(2), 85-124.

Bozkurt, A. (2020). Coronavirus (Covid-19) pandemic process and evaluations for education in the post-pandemic world: New normal and new education paradigm. Journal of Open Education Applications and Research, 6(3), 112-142.

Çakın, M., and Külekçi Akyavuz, E. (2020). The Covid-19 process and its reflection on education: An analysis on teachers' opinions. International Journal of Social Sciences and Education Research, 6(2), 165-186. DOI: 10.24289/ijsser.747901

Can, E. (2020). Coronavirus (Covidien-19) pandemic and pedagogical implications: open and distance education applications in Turkey. Journal of Open Education Applications and Research, 6 (2), 11-53.

Can, Y., and Soyer, F. (2008). The relationship between physical education teachers' socio-economic expectations and job satisfaction. Gazi University Journal of Gazi Educational Faculty (GUJGEF), 28(1). 
Çelik, S. (1999). The effects of job satisfaction and motivation on job performance. Master's thesis, Institute of Social Sciences, Marmara University: Istanbul.

Chen, L. (2008). Job satisfaction among information system (is) personal. Computer in Human Behavior, 24 (1), 105-118.

Deci, E.L. and Ryan, R.M. (1985). Intrinsic motivation and self-determination in human behavior. Plenum, New York, NY.

Demir, F., and Özdaş, F. (2020). Examınıng teachers' opınıons related to distance education in the covid-19 process. Journal of National Education, 49(1), 273-292. https://doi.org/10.37669/milliegitim.775620

Deniz, Ü., and Erdener, M. A. (2016). Factors affecting teachers' job motivation. In Tüfekçi, Ö. K. (Ed.). Strategic Research in Social Sciences, (p.29-41). Saarbrücken: Lambert Academic Publishing

WHO. (2020). Mental health and psychosocial considerations during the COVID-19 outbreak. Retrieved from https://www.who.int/docs/default-source/coronaviruse/mentalhealth-considerations.pdf 01 December 2020

Elliot, A. J., and Covington, M. V. (2001). Approach and avoidance motivation. Educational Psychology Review, 13(2), 73-92. https://doi.org/10.1023/A:1009009018235

Ertürk Kara, H. G., and Gözcü, S. (2015). Teachers' and parents' views on school readiness: a phenomenological study. Journal of Kirsehir Education Faculty, 16(2).

European Physical Education Association (2020). Physical education in Europe and COVID 19: The situation in Europe after COVID 19, No education without physical education. First EUPEA Physical Education Online Meeting, Retrieved from https://eupea.com/wp-content/uploads/2020/06/200626-EUPEA-Covid19-Questionnaire-II.pdf, 23 June 2020.

Gençay, Ö. A. (2007). Examination of job satısfaction and burnout levels of physical educators according to the some variables. Kastamonu Education Journal, 15(2), 765-780.

Gewin, V. (2020). Five tips for moving teaching online as COVID-19 takes hold. Nature, 580(7802), 295-296.3

Günbayı, İ. (2000). Job satisfaction and motivation in organizations. Ankara: Özen Publishing.

Halcomb, E. J., and Andrew, S. (2005). Triangulation as a method for contemporary nursing research. Nurse researcher, 13(2). doi: 10.7748/nr.13.2.71.s8

Huitt, W. (2011). Motivation to learn: An overview. Educational Psychology Interactive. Valdosta, GA: Valdosta State University. 
Karadeniz, G., and Zabc, N. (2020). The effects of teachers' experiences during the pandemic period, their well-being, stress levels and adaptation to distance education. MSGSÜ Journal of Social Sciences, 2(22), 301-314.

Keskin, M., \& Özer Kaya, D. (2020). Evaluation of students' feedbacks on web-based distance education in the covid-19 process. İzmir Katip Çelebi University Journal of Health Sciences Faculty, 5(2), 59-67.

Kurnaz, A., Kaynar, H., Barışık, C. Ş., and Doğrukök, B. (2020). Teachers' views on distance learning. Journal of National Education,49(1), 293-322. https://doi.org/10.37669/milliegitim.787959

Lau, J., Yang, B., and Dasgupta, R. (2020). Will the coronavirus make online education go viral. Times Higher Education, 12.

Lincoln, Y.S., and Guba, E.G. (1985) Naturalistic mquiry. SAGE, Thousand Oaks, 289-331. http://dx.doi.org/10.1016/0147-1767(85)90062-8

Locke, E.A. (1997). The motivation to work: What we know, in Maehr, M.L. and Pintrich, P.R. (Eds), Advances in Motivation and Achievement, p. 375-412. JAI Press Inc., Greenwich, CT.

Martn, A.J. (2001). The student motivation scale: A tool for measuring and enhancing motivation. Australian Journal of Guidance and Counseling, 11, 1-20.

Meece, J. L. Glienke, B. B., and Burg, S. (2006). Gender and motivation. Journal of School Psychology, 44, 351-373.

Merriam, S. B. (2009). Qualitative research: A guide to design and implementation. San Francisco, CA: Jossey- Bass.

Miles, M. B. and Huberman, A. M. (1994). Qualitative data analysis. (2nd edition). Thousand Oaks, CA: Sage.

Morse, J. M., Barrett, M., Mayan, M., Olson, K., and Spiers, J. (2002). Verification strategies for establishing reliability and validity in qualitative research. International Journal of Qualitative Methods, 1(2), 13-22. https://doi.org/10.1177/160940690200100202

Özdemir, S., and Cemaloğlu, N. (2017). Organizational behavior and management. Ankara: Pegem publishing

Özgül, E., Ceran, D., and Yıldız, D. (2020). Evaluation of turkısh course with distance education according to teachers' views. Journal of National Education, 49(1), 395412. https://doi.org $/ 10.37669 /$ milliegitim.776137

Robbins, S. P., Coulter, M., and DeCenzo, A. D. (2017). Fundamentals of management. Pearson: England

Roberts, P. and Priest, H. (2006). Reliability and validity in research. Nursing standard, 20(44),41-46. 
Sá, M. J., and Serpa, S. (2020). The Global Crisis Brought about by SARS-CoV-2 and Its Impacts on Education: An overview of the Portuguese Panorama. Science Insights Education Frontiers, 5(2), 525-530.

Saban, A. (2007). Postgraduate students' perceptions of qualitative research methodology. Selçuk University Journal of Social Sciences Institute, 1(17), 469-485.

Sarı, T., and Nayır, F. (2020). Education in the pandemic period: Challenges and opportunities. Electronic Turkish Studies, 15(4).

Şenol, C., and Bilsel, A. (2020). Status of COVID-19 (Coronavirus) Pandemic in Turkey and Future Status Analysis According to Algorithmic Calculation, Journal of Social, Humanities and Administrative Sciences, 6(25), 535-546. Doi:10.31589/joshas.296

Serçemeli, M., and Kurnaz, E. (2020). A research on students' perspectives to distance education and distance accounting education in the covid-19 pandemia period. International Journal of Social Sciences Academic Research, 4(1), 40-53.

Telli-Yamamoto, G., and Altun, D. (2020). The coronavirus and the rising of online education. Journal of University Studies, 3 (1), 25-34. Doi: 10.32329/uad.711110

Tison, G. H., Avram, R., Kuhar, P., Abreau, S., Marcus, G. M., Pletcher, M. J., and Olgin, J. E. (2020). Worldwide effect of COVID-19 on physical activity: A descriptive study. Annals of Internal Medicine, 173(9), 767-770.

Van De Berghe L, Cardon G, Aelterman N, Tallir IB, Vansteenkiste M, and Haerens, L. (2013). Emotional exhaustion and motivation in physical education teachers: a variable-centered and person-centered approach. J Teach Phys Educ, 32, 30520.

Varea, V., and G. González-Calvo. (2020). Touchless classes and absent bodies: Teaching physical education in times of covid-19. Sport, Education and Society. doi:10.1080/13573322.2020.1791814

Varea, V., G. González-Calvo and A. García-Monge (2020). Exploring the changes of physical education in the age of Covid-19. Physical Education and Sport Pedagogy. DOI: $10.1080 / 17408989.2020 .1861233$

West, P. W. (2016). Simple random sampling of individual items in the absence of a sampling frame that lists the individuals. New Zealand Journal of Forestry Science, 46(15), 1-7. DOI 10.1186/s40490-016-0071-1

Yildırım, A., and Şimşek, H. (2013). Qualitative research methods in the social sciences. 9. Edition, Ankara: Seçkin Publications.

Yıldız, E., and Seferoğlu, S. (2020). Examination of self-efficacy perception of distance education students about online technologies. Celal Bayar University Journal of Social Sciences, 18(1), 33-46. 
Zhang, W., Wang, Y., Yang, L., and Wang, C. (2020). Suspending classes without stopping learning: China's education emergency management policy in the COVID-19 outbreak. Journal of Risk and Financial Management, 13(3), 3-6. https://doi. org/10.3390/jrfm13030055

\section{Kaynakça Bilgisi / Citation Information}

Kızılkaya Namlı, A. and Yücekaya, M. A. (2021). Motivation and job satisfaction of physical education teachers during pandemic. OPUSInternational Journal of Society Researches, 17(Pandemi Özel sayısı), 3148-3172. DOI: $10.26466 /$ opus.887856 